Ryszard Kleszcz

Uniwersytet Łódzki

Instytut Filozofii

Katedra Logiki i Metodologii Nauk

\section{Filozofia a religia}

[...] nie ma rzeczy nietykalnych, gdy chodzi o zagadnienia, jakie można rozważać, lecz należy bardzo mocno przestrzegać standardów precyzji i jasności $w$ ich rozważaniu.

Dorothy Mary Emmet

Podejmowanie zagadnienia relacji filozofii i religii stawia nas wobec kilku trudności, mających skomplikowany charakter, bez rozstrzygnięcia których nie da się odpowiedzialnie mówić o tym zagadnieniu. Ustalę przy tym od razu, że mówiąc o filozofii, mam na myśli filozofię zachodnią, powstałą w antycznej Grecji i liczącą sobie dwadzieścia sześć wieków. Przyjmijmy także, że filozofia może zajmować się religią na zupełnie podobnej zasadzie jak ta, która pozwala jej czynić przedmiotem filozoficznego namysłu naukę, moralność, sztukę czy politykę. Każda z tych dziedzin jest interesująca dla filozofii, zaś dla niektórych filozofów staje się przedmiotem filozoficznej eksploracji. Uczynienie religii przedmiotem filozoficznych badań wymaga dookreślenia jej przedmiotu. Religia jest zjawiskiem ogromnie złożonym i mówienie o religii w ogóle zdaje się rodzić trudne do pokonania przeszkody'. Należy więc dokonać pewnych ograniczeń. I tak jak przyjąłem, mówiąc o filozofii, że mam na myśli filozofię zachodnią, tak samo mówiąc o religii, chciałbym mieć na myśli wielkie religie światowe (buddyzm, chreścijaństwo, hinduizm, islam i judaizm). Ponieważ takie ograniczenie też jeszcze komplikowałoby dalsze analizy, to uczynimy krok dalej i ograniczymy się do chrześcijaństwa. To chrześcijaństwo bowiem było głównym przedmiotem odniesienia filozofii zachodniej. Czyniąc tak, pozostajemy na gruncie kultury, która kształtowała

1 Jak zauważa J. Haldane: „There is no such thing as »religion in general«, any more than there is any such creature as an »animal in general«. Euery animal is of some of other species, and each has its own distinguishing marks". Por. J. $\mathrm{H}$ a I d a n e, An Intelligent Person's Guide to Religion, London-New York-Woodstock 2005, s. 12. 
naszą przeszłość i dzień dzisiejszy. Filozofia grecka i religia chrześcijańska są fundamentalnymi źródłami tejże kultury. W dalszym ciągu należy więc powiedzieć coś więcej o tych dwu fundamentach kulturowych winteresującej nas perspektywie relacji filozofia-religia.

Mówiąc o filozofii, nie da się uniknąć wskazania, jak rozumiemy ten dział kultury. Otóż filozofię będę traktował jako rodzaj myślenia teoretycznego, w obrębie którego dąży się do sformułowania, zwykle ogólnych, pytań dotyczących świata, człowieka i kategorii naszego poznania oraz udzielenia na te pytania odpowiedzi ${ }^{2}$. Stawiane $w$ filozofii pytania oraz udzielane odpowiedzi wyrażane są zwykle $w$ języku naturalnym, choć filozofia dysponuje narzędziami w postaci logiki, które doskonalą się $w$ miarę rozwoju tej dyscypliny. Powstanie nowoczesnej postaci logiki, której techniki wnoszą coś ważnego do rozpatrywania klasycznych sporów, wywiera istotny wpływ na obecny stan filozofii. Niezależnie od stosowania narzędzi formalno-logicznych, kluczową rolę dla filozofii odgrywa to, co w Szkole Lwowsko-Warszawskiej określano mianem analizy semiotycznej. To dzięki niej możemy precyzować znaczenia używanych terminów i usuwać rozmaitego rodzaju wadliwości językowe. Tak więc przedmiotem troski filozofa jest $z$ jednej strony dążenie do precyzyjnego ustalenia znaczenia analizowanych przekonań, z drugiej zaś wskazanie, jakie racje przemawiają na ich rzecz. Innymi słowy analiza i argumentacja to dwa kluczowe elementy, wykorzystywane przez filozofów $w$ ich badaniach. Te powyższe uwagi skłonić mogą do sformułowania tezy, że dla autora tych słów bliska jest filozofia zwana analityczną. Rozwiewając wszelkie wątpliwości, pragnę potwierdzić takie podejrzenia. Rzeczywiście utożsamiam się z podejściem analitycznym, choć dodać muszę, że nie wszystkie nurty analizy są mi jednakowo bliskie.

W dalszym ciągu rozważań należy sformułować określenie religii. W jej przypadku stajemy, podobnie jak w przypadku słowa „kultura”, wobec zasadniczych trudności, które związane są ze znaczną ilością znaczeń przypisywanych obydwu terminom. Rozmaite definicje religii kładą często nacisk na jeden z elementów charakterystycznych dla zjawiska religii ${ }^{3}$. Takim elementem centralnym w proponowanej definicji może być wiara w Boga (bogów) lub też ukierunkowanie na coś ważnego, uznanego

2 Por. R. K l e s z c z, Co to jest filozofia?, „Ruch Filozoficzny” 2003, t. 6o, z. 4, s. 527-531. Tam to rozumienie filozofii poddawane jest bliższej analizie.

3 Por. W. A I st o n, Religion, [w:] The Encyclopedia of Philosophy, ed. P. Edwards, New York-London 1967, vol. 7, s. 140 i nast. Tam znajdujemy przegląd rozmaitych definicji religii. 
za warte najwyższej $\mathrm{czci}^{4}$. Nie chcąc wdawać się w szczegółowe spory dotyczące definicji religii, trzymać się będę takiego użycia tego terminu, który odsyła nas do wielkich religii światowych, z których interesuje mnie głównie chrześcijaństwo. Otóż $w$ kontekście tych religii, a już niewątpliwie w odniesieniu do chrześcijaństwa, wyróżnić możemy cztery komponenty składające się na religię. Są to:

1) system przekonaniowy, który $w$ przypadku religii chreścijańskiej obejmuje tezy: o istnieniu Boga, posiadającego takie atrybuty, jak wszechmoc, wszechwiedza i bycie dobrym; stworzenie Przezeń świata i człowieka itd.;

2) system zachowań, na który składają się rozmaite praktyki religijne. Istotną rolę odgrywa element kultowy (liturgiczny). Zachowania i praktyki religijne mogą być powszechne (modlitwy, posty) lub też dostępne tylko dla niektórych (przeżycia mistyczne);

3) postawy wobec Boga, takie jak: cześć, poczucie zależności, poddania, trwogi itd.; wiele o tym mówi w swej klasycznej pracy Das Heilige Rudolf Otto;

4) kodeks moralny obejmujący reguły postępowania życiowego. Jego autorem ma być Bóg lub założyciel danej religii.

Można powiedzieć, że dla filozofa religia to pewne przekonania oraz zuiązane z tymi przekonaniami zaangażowania. Jeśli rozumieć religię $w$ ten sposób, to należy odrzucić pogląd, że dla religii nie jest ważna sfera przekonań, a liczy się jedynie zaangażowanie, który to pogląd żywiony jest za Ludwigiem Wittgensteinem przez niektórych jego kontynuatorów. Zwraca na to uwagę Roger Trigg, podkreślając, że: „Zawsze muszę być zaangażowany w coś lub w kogoś. Jeśli angażuję się w Boga, opieram me życie na przeświadczeniu, że istnieje Bóg. Ów fakt, że nasze zaangażowania nigdy nie mogą »krążyć swobodnie«, lecz zawsze są gdzieś skierowane, oznacza, że za każdym zaangażowaniem musi tkwić element sądu. Muszę mieć jakiś pogląd na to, w co jestem zaangażowany. Nie mogę więc być zaangażowany w Boga, jeśli jestem przeświadczony, że nie ma Boga"5.

Trudno więc nie uznawać za ekscentryczny poglądu, w przypadku którego zaangażowanie na rzecz religii łączyłoby się z przekonaniem, że sąd o istnieniu Boga jest fałszywy.

4 Por. odpowiednio definicje C. A. Campbella („Religia to wiara w realność nadprzyrodzonej istoty") w: te n ż e, On Selfhood and Godhood, London 1957, s. 20 oraz I. J. B a r b o u r a („Religia to całościowe ukierunkowanie życia na coś, co jest uznawane za godne najwyższego zainteresowania i czci") w: t e n ż e, Issues in Science and Religion, London 1966, s. 10.

5 Por. R. Trig g, Rozum a zaangażowanie, przeł. B. Stanosz, Warszawa 1977, s. 41; t e n ż e, Rationality and Religion, Orford 1998, s. 134-153. 
Religia jest działem kultury zdecydowanie starszym od filozofii, a od powstania tej ostatniej wchodzi z nią w rozmaite interakcje. Chrześcijaństwo nie jest filozofią, ale niesie przesłanie, które nie jest neutralne filozoficznie. Trafnie, moim zdaniem, ujmuje to Michael Dummett, stwierdzając, że: „Każda religia dostarcza jej wyznawcy nie tyle całościowej koncepcji świata, ile pewnych wyraźnych wyznaczników takiej koncepcji, pozwalając im na dwie rzeczy: na zdecydowanie, jak powinni ułożyć sobie życie, i na nadanie pewnego sensu zachodzącym zdarzeniom, poprzez przypisanie im doniosłości i celu" ${ }^{6}$.

Takimi komponentami przekonań religijnych chrześcijańskich będą tezy: o istnieniu osobowego Boga, doktryna trynitarna, o wcieleniu, o stworzeniu świata ex nihilo, o stworzeniu człowieka na podobieństwo Boga itd. Chrześcijanie już w II wieku po Chrystusie wiedzieli, że wiara przez nich wyznawana ma wagę metafizyczną. Zaczęli też wykorzystywać greckie narzędzia filozoficzne dla jej wyrażenia. Chrześcijaństwo jako religia pozostawało więc w związku z filozofią, korzystając z tych jej narzędzi, które uznano za ważne dla wyrażenia jego przesłania. Jak to zauważa Frederick C. Copleston, „[...] w procesie poszukiwania przez wiarę zrozumienia samej siebie musi wystąpić, $w$ tym lub innym punkcie, refleksja, którą można zasadnie scharakteryzować jako metafizyczną"7.

Zarazem jednak sama religia wpływała na filozofię. Metafizyka zachodnia wydaje się $w$ jakiejś mierze wyrażać autentyczny impuls religijny czy też religijną orientację ${ }^{8}$. Prowadzić to zresztą może do takich konsekwencji, że osłabienie ducha religijnego $w$ danym okresie bądź kręgu wiązać się będzie z osłabieniem zainteresowania metafizyką9. Te wzajemne zależności między religią i filozofią są dostrzegane przez rozmaitych, także współczesnych, autorów. Wskazuje na to Alfred N. Whitehead, podkreślając, że religia wymaga wsparcia metafizycznego, bez którego jej autorytetowi grozi siła emocji, ale zarazem sama religia wnosi wkład do metafizyki, dostarczając intuicji służących ugruntowaniu doktryny metafizycznej ${ }^{10}$.

6 Por. M. D u m m e t t, Natura i przyszłość filozofii, przeł. T. Szubka, Warszawa 2010, s. 54.

7 Por. F. C. C o p l e s t o n, Religia i filozofia, przeł. B. Stanosz, Warszawa 1978, s. 58.

8 Por. tamże, s. 10. Ogólnie na temat wpływu religii na filozofię zachodnią por:: P. B ö h n e r, E. G i l s o n, Historia filozofii chrześcijańskiej. Od Justyna do Mikołaja Kuzańczyka, przeł. S. Stomma, Warszawa 1962, s. 9-23; F. C. C o p l e s t o n, Religia i..., s. 9-95; S. M a c D o n a ld, The Christian Contribution to Medieval Theology, [w:] A Companion to Philosophy of Religion, ed. P. L. Quinn, Ch. Talliaferro, Orford 1999, s. 80-87; S. S w i e ż a w s k i, Dzieje europejskiej filozofii klasycznej, Warszawa-Wrocław 200o, s. 251-258.

9 Por. uwagi G. R y l e' a w: The Nature of Metaphysics, ed. D. F. Pears, New York 1957, S. 160 .

10 Por. A. N. W h i t e h e a d, Religia w tworzeniu, przeł. A. Szostkiewicz, Kraków 1997, S. 79,81 . 
Postawmy teraz pytanie, co filozofa, a zwłaszcza filozofa analitycznego, interesuje $w$ religii. Ze wskazanych czterech komponentów religii kluczowy jest element pierwszy, czyli system przekonań religijnych, do którego można włączyć także przekonania moralne charakterystyczne dla religii. Pozostałe płaszczyzny będą $w$ znacznie mniejszym stopniu przedmiotem zainteresowań filozofa. Analityk jest więc, jako filozof, zainteresowany sferą intelektualną religii. Ta warstwa przekonań jest bogata, ale kluczowa jest teza o istnieniu Boga. Z wyznawaniem religii wiąże się uznawanie pewnych sądów, przede wszystkim zaś sądu mówiącego o istnieniu bytu boskiego.

Filozoficzny namysł nad przekonaniami religijnymi zmierza $w$ dwu kierunkach. Po pierwsze, będzie to płaszczyzna analizy językowej, dzięki której można uzyskać interpretację danego sądu (sądów) i uznać, że jest on sensowny i przysługuje mu takie a takie znaczenie. Czyli ogólnie mówiąc, byłby to namysł nad językiem religii. Po drugie zaś, będzie to analiza racji przytaczanych na rzecz przekonań religijnych. W filozofii i teologii chrześcijańskiej przyjmuje się zwykle, że wśród przekonań religijnych są takie, które są wywiedzione z objawienia religijnego, i takie, które podlegają racjonalnej argumentacji. Zwykle uznaje się, że zdecydowana większość należy do tej drugiej kategorii. Generalnie możemy więc stwierdzić, że filozof ma dwa zadania w swej refleksji nad religią. Po pierwsze, pragnie ustalić znaczenie słowa „Bóg”, czy też innych słów kluczowych dla przekonań religijnych, po drugie zaś, dąży do przeanalizowania racji pro i contra na recz istnienia bytu boskiego czy analogicznie innych branych pod uwagę przekonań.

Gdy mówimy, że filozofia może czynić religię przedmiotem swych badań, to współcześnie ich przedmiotem jest, przede wszystkim, dział filozofii, jakim jest filozofia religii. Ten dział filozofii bywa rozmaicie charakteryzowany. Przyjmijmy jednak, że filozofia religii będzie dla nas dyscypliną, która bada znaczenie tez religijnych (odpowiednich przekonań) oraz ich uzasadnienia. Samo to pojęcie pojawiło się w XVIII wieku, choć upowszechniło $w$ wieku $X X^{11}$. Problematyka filozofii religii i religii w ogóle zdaje się wzbudzać spore zainteresowanie współczesnych filozofów. W odniesieniu do myśli filozoficznej angloamerykańskiej tak o tym mówi Richard Swinburne: „Od ostatnich dwudziestu lat można dostrzec znaczny wzrost zainteresowania filozofią religii, zarówno w USA, jak i w Wielkiej

${ }^{11}$ Stało się tak m.in. dlatego, że część filozofów pomijała w swych pracach zagadnienie Boga i religii. W każdym razie od XIX w. stało się to coraz częstszą praktyką. To też było przyczyną ukształtowania się filozofii religii. Uwagi historyczne por. w: M. J. C h a r l e s w o r t h, Philosophy of Religion. The Historic Approaches, London 1972, passim. 
Brytanii. Dla przykładu, gdy studiowałem filozofię w Oksfordzie, nie było specjalnego przedmiotu zwanego filozofią religii, który studenci mogliby wybrać i studiować. Obecnie filozofia religii jest popularną opcją w zakresie studiów filozoficznych i około 60 lub 70 oksfordzkich studentów pisze każdego roku pracę z tej dziedziny"12.

Tak więc analityczni filozofowie zmienili, w jakiejś części, niechętny czy obojętny stosunek wobec tej problematyki. Jest to z jednej strony wynikiem zmierzchu antymetafizycznego nastawienia części tych filozofów, z drugiej zaś tego, że analityczna filozofia religii reprezentuje wysokie standardy, podobne do tych z innych działów filozofii analitycznej.

Zagadnienie języka religijnego to problem, który dopiero w XX wieku stał się przedmiotem szerszych zainteresowań. Przy czym samo podejście do tego rodzaju języka ulegało $w$ minionym wieku znacznym przemianom. Wspomnijmy w tym miejscu o dwu tylko podejściach: typowym dla empiryzmu logicznego oraz o stanowisku L. Wittgensteina. Tendencje neopozytywistyczne znajdujące wyraz $w$ Kole Wiedeńskim były wobec tego typu języka całkowicie destrukcyjne. Reprezentatywne dla tego nurtu poglądy wyrażał, na gruncie anglosaskim, Alfred J. Ayer. W swej popularnej pracy Language, Truth and Logic z 1936 roku traktuje on zdania religijne i metafizyczne jako znajdujące się poza sferą zdań sensownych, do których byłyby zaliczane tylko zdania analityczne (tautologie) oraz zdania empiryczne. W przypadku tych ostatnich ich wartość byłaby wyznaczana przez fakty doświadczenia. Zdania o Bogu, tak jak Go rozumie monoteizm, nie byłyby $w$ efekcie zdaniami sensownymi. Tak to wyraża A. Ayer: „What is not so generally recognised is that there can be no way of proving that the existence of a god, such as the God of Christianity, is even probable. Yet this also is easily shown. For if the existence of such a god were probable, then the proposition that he existed would be an empirical hypothesis And if "god « is a metaphysical term, then if cannot be even probable that a god exists. For to say that »God exists « is to make a metaphysical utterance which cannot possess any literal significance"13.

To stanowisko A. Ayera, modelowo reprezentujące podejścia posługujące się pojęciem sensu empirycznego, może być zasadnie krytykowane na płaszczyźnie metafilozoficznej, co $w$ odniesieniu do neopozytywizmu w ogóle czynił skutecznie choćby Roman Ingarden ${ }^{14}$. Ale zasadne może być także poddanie krytyce tego, że nie dostrzega się na gruncie takiego

${ }_{12}$ Por. Analiza i religia. Rozmowa z Profesorem Richardem Swinburnem, rozm. T. Szubka, „Znak” 1994, nr 4, s. 71.

13 Por. A. J. A y e r, Language, Truth and Logic, New York 1952, s. 115.

14 Por. R. I n g a r d e n, Próba przebudowy filozofii przez neopozytywistów, [w:] t e n ż e, Z badań nad filozofia współczesna, Warszawa 1963, s. 654-662. 
podejścia wielości i rozmaitości ról pełnionych przez wypowiedzi językowe. Te aspekty były podnoszone $w$ refleksji „drugiego” Wittgensteina, kładącego nacisk na istnienie wielu gier językowych, posiadających właściwe sobie reguły poprawności ${ }^{15}$. W przypadku języka religijnego ma on właściwe dla siebie reguły, które nie wymagają odwoływania się do zabiegów uzasadniających ${ }^{16}$. Koncepcja L. Wittgensteina wydobywa istotne aspekty języka religijnego, równocześnie jednak trudno zgodzić się z tym jej komponentem, który traktuje język religijny jako całkowicie odrębny typ języka. Całościowo ujmowana koncepcja L. Wittgensteina budzi zasadnicze wątpliwości ${ }^{17}$.

W tym momencie przyjmijmy wstępnie, że język religijny to język naturalny wykorzystywany w sytuacjach religijnych. Mielibyśmy więc do czynienia ze zwykłym językiem J, wykorzystywanym w rozmaitych kontekstach religijnych. Dla filozofa istotne staje się pytanie dotyczące statusu poznawczego językowych wypowiedzi religijnych. W pierwszym rzędzie pytania o ich sensowność, a następnie o ich uzasadnienie. Przyjmijmy, że $w$ tym momencie interesują nas wypowiedzi o Bogu, takie jak: „Bóg stworzył niebo i ziemię” czy „Bóg jest dobry”18. Analizując te wypowiedzi, łatwo zauważyć, że stwarzanie świata przez Boga różni się od powoływania czegoś do istnienia przez człowieka. Stwarzanie boskie jest przecież powoływaniem do istnienia całej rzeczywistości, w tym czasu i przestrzeni ${ }^{19}$. Podobnie, gdy mówimy, że przypisywanie Bogu bycia dobrym musi znaczyć coś innego, niż orzekanie tego w odniesieniu do bytów ludzkich ${ }^{20}$. Bóg, jeśli jest dobry, to $w$ innym sensie i zakresie niż np. Święty Franciszek czy Matka Teresa z Kalkuty. Nasuwa się więc wniosek, że wypowiedzi o Bogu nie będą mogły być rozumiane dosłownie, skoro Bóg chrześcijański jest bytem transcendentnym.

15 Por. L. W i t t g e n s t e i n, Dociekania filozoficzne, przeł. B. Wolniewicz, Warszawa 2000, s. 20, gdzie czytamy: „Lecz ile jest rodzajów zdań? Stwierdzanie, pytanie i rozkaz? - Istnieje niezliczona ich ilość: niezliczona ilość sposobów użycia tego wszystkiego, co zwiemy »znakiem«, »słowem«, »zdaniem«. I mnogość ta nie jest czymś stałym, raz na zawsze danym; powstają bowiem, można rzec, nowe typy języka, nowe gry językowe, a inne stają się przestarzałe i idą w zapomnienie"; również tamże: §§ 24 i 25.

16 Por. L. W ittge n s te i n, Lectures and Conversation on Aesthetics, Psychology and Religious Belief, ed. C. Barrett, Orford 1970, s. 52-60.

17 Szerzej piszę na ten temat w: R. K l e s z c z, O rozumie i wartościach, tódź, 2007, s. 90-106. Zob. także R. Tr i g g, Rozum a zaangażowanie, s. 27-31.

18 Jak podkreśla F. C. Copleston, w filozofii zachodniej dyskusja nad językiem religijnym skupia się na wypowiedziach o Bogu. Por. F. C. C o p l e s t o n, Religia i filozofia, s. 61.

19 Por. H. M c C a n n, Creation and Conservation, [w:] A Companion to Philosophy of Religion, eds. P. L. Quinn, Ch. Talliaferro, s. 306-312.

20 Por. P. H e l m, Goodness, [w:] A Companion..., s. 243-249. 
Przyjmijmy teraz, że rzeczywistość, o której mówi się w religii, nazwiemy $\mathbf{R}$ - rzeczywistością. Różni się ona od rzeczywistości doświadczenia potocznego czy naukowego, którą określić możemy mianem $\mathbf{N}$ - rzeczywistości ${ }^{21}$. Naszym językiem, w którym mówimy o $\mathbf{N}$ - rzeczywistości jest J. Jeśli uznać, że mówiąc o $\mathbf{R}$ - rzeczywistości, nie da się stosować predykatów odnoszących się do $\mathbf{N}$ - rzeczywistości, to użycie języka $\mathbf{J}$ jest niewystarczające. W takiej sytuacji rysuje się kilka możliwych dróg wyjścia i uporania się z problemem. Poniżej wskazuję na trzy z nich.

1) Można uznać, że o transcendentnym Bogu nie da się w ogóle mówić. Zauważmy na marginesie, że nieadekwatność ludzkiego mówienia o Bogu jest widoczna $w$ radykalnym monoteizmie Żydów, dla których Bóg jest zbyt święty, aby mógł być nazwany. Taka jest droga teologii negatywnej wytyczona przez Pseudo-Dionizego Areopagitę w jego Imionach boskich ${ }^{22}$. Na gruncie teologii negatywnej nie daje się mówić o Bogu ( $\mathbf{R}$ - rzeczywistości) nie tylko przy pomocy $\mathbf{J}$, ale jakiegokolwiek języka w ogóle.

2) Język religijny to język o charakterze metaforycznym. Może on nabyć walorów poznawczych, ale pod warunkiem znalezienia odpowiednich modeli i metafor ${ }^{23}$.

3) Trzecią drogą byłoby odwołanie się do Tomaszowej teorii analogii. Oznacza to przyjęcie tezy, że mamy do czynienia z takim używaniem słów, których znaczenia nie są ani jednoznaczne, ani wieloznaczne, tylko analogiczne $^{24}$. Powstaje jednak pytanie, czy daje się z tego narzędzia skorzystać, mówiąc o takich kategoriach, jak: dobro, stwarzanie czy wszechmoc.

Z powyższych trzech propozycji poważne wątpliwości budzi pierwsza z nich, to znaczy teologia negatywna ${ }^{25}$. Niezależnie od pewnych jej zalet, które nie umknęły uwadze racjonalisty Tomasza, należy stwierdzić, że nie

${ }^{21}$ Warto zauważyć, że aby mówić o $\mathrm{R}$ - rzeczywistości, można być religijnym agnostykiem czy ateistą. Wystarczy tylko uznanie, że akty wiary religijnej mają intencjonalny charakter. W ten sposób mają one swoje przedmioty, dla jednych realne, a dla innych nie. Por. J. Wo l e ń s k i, Jak opisywać nieopisywalne. O granicach języka religijnego, „Więź" 2011, nr 2/3, s. 59 i nast.

${ }^{22}$ Por. P s e u d o-D i o n i z y A re o p a g i t a, Imiona boskie, [w:] t e n ż e, Pisma teologiczne, przeł. M. Dzielska, t. 1, Kraków 1997, s. 45-16o, passim.

${ }_{23}$ Por. J. M. S o s k i c e, Metaphor and Religious Language, Ouford 1984, passim.

24 Jak zauważa Św. Tomasz: „Na podstawie tego, co powiedzieliśmy, należy stwierdzić, że o Bogu i o stworzeniach nie orzeka się ani jednoznacznie, ani wieloznacznie, lecz analogicznie, to znaczy według przyporządkowania lub stosunku do czegoś jednego". Por. t e n ż e, Summa contra gentiles, przeł. Z. Włodek, W. Zega, Poznań 2003, s. 106.

${ }^{25}$ Zdecydowanym przeciwnikiem teologii negatywnej jest R. Swinburne. Por. t e n ż e, Spójność teizmu, przeł. T. Szubka, Kraków 1995, s. 125. 
daje ona żadnej pozytywnej wiedzy o Bogu. Tymczasem tak Biblia, jak i zwykli wierni, mówiąc o Bogu, stwierdzają, że „jest dobry”, ,jest stworzycielem”, ,jest wierny” itd. Trudno w takiej sytuacji zadowolić się tylko i wyłącznie drogą zalecaną przez teologię negatywną, chcąc coś mówić o R - rzeczywistości. Drugą drogą byłoby konstruowanie metaforycznego języka, w którym mówiłoby się o Bogu, czyli jakiegoś języka Jm. Zgodzić się można, że mówiąc o $\mathbf{R}$ - rzeczywistości używa się niekiedy języka metaforycznego, jak to na przykład bywa wtedy, gdy wierny mówi: „Bóg jest moją fortecą". Ale w wielu przypadkach użycia języka religijnego nie chodzi o sens metaforyczny. Tak jest choćby w przypadku takich stwierdzeń, jak: „Bóg jest mądry”, „Bóg jest dobry”, „Bóg jest wszechmocny”, kiedy nie sens metaforyczny wchodzi w grę. Istniejące propozycje, związane z metaforycznym rozumieniem języka religijnego, rodzą rozmaite wątpliwości. Tak jest choćby w przypadku koncepcji Iana T. Ramsaya, która budzi szereg pytań i wątpliwości, w tym podobne do tych formułowanych pod adresem koncepcji L. Wittgensteina ${ }^{26}$. I. Ramsey przyjmuje, że mówiąc o R - rzeczywistości (Bogu), tworzy się modele teoretyczne doświadczenia, które jest specyficznym doświadczeniem religijnym ${ }^{27}$. I. Ramsey operuje tzw. modelami otwarcia, w których coś (jakieś r) ujmowane jest jako izomorficzne z Bogiem ze względu na posiadanie podobnej struktury. Ten model tylko wskazuje na Boga, nie będąc jego opisem. W efekcie to, co nazywa się doświadczeniem otwarcia, staje się punktem wyjścia do budowy modeli wskazujących na Boga (sferę nieempiryczną). W koncepcji tej w podobieństwie do Wittgensteinowskiej nacisk kładziony jest na sferę zaangażowania religijnego, z lekceważeniem komponentu przekonaniowego ${ }^{28}$.

Te uwagi krytyczne wobec wspomnianych koncepcji łączyć można z pytaniem, czy najlepszym rozwiązaniem nie byłoby sięgnięcie do teorii języka analogicznego. Warto od razu zauważyć - nie powinna to być analogia w wersji klasycznej, wykorzystywana przez myślicieli neotomistycznych, lecz jakaś wersja zmodyfikowana. Taka jest, jak się wydaje, koncepcja zarysowana przez R. Swinburne’a. W jego ujęciu korzystamy z użycia analogicznego, w takim sensie, że zmieniamy znaczenie słów poprzez ich poszerzenie lub zawężenie. Oznacza to zmodyfikowanie roli

26 Ta koncepcja wyrażona jest, przede wszystkim, w pracy I. R a m s e y a Religious Language, London 1957.

${ }^{27}$ Stąd język religijny byłby, w jego ujęciu, specyficzny, wymagając użycia orzeczników w sposób ani jednoznaczny, ani wieloznaczny, ani analogiczny.

${ }^{28}$ Uwagi krytyczne na ten temat znajdujemy w: R. Trig g, Rozum a..., s. 66-74, zułaszcza s. 71-73. 
standardowych przykładów $w$ regułach semantycznych i/lub syntaktycznych poprzez rezygnację z niektórych z nich ${ }^{29}$. Teista, dokonując takiego zabiegu modyfikacji, czyni coś, co R. Swinburne nazywa użyciem analogicznym. Trzeba zauważyć, że takie zabiegi nie są całkiem obce naukom przyrodniczym, w obrębie których używa się na przykład słów "fala” i „cząstka”, dokonując takich zmian reguł semantycznych. R. Swinburne zauważa zarazem, że katalog użytych analogicznie wyrażeń nie może być zbyt obszerny, wtedy bowiem wraz z jego rozbudową zmniejsza się ilość przekazywanych informacji: „Nadając słowom sensy analogiczne, teista musi unikać zbytniego rozluźniania ich znaczeń. Karta pod nazwą »sens analogiczny « jest dopuszczalna, jak to pokazują przywoływane przykłady, lecz nie należy grać nią zbyt często - im bowiem częściej się nią gra, tym mniej będzie przekazane przez to, co się mówi"3o

Prowadzone przez filozofa brytyjskiego analizy dotyczą takich terminów, jak: „wszechmoc”, „wszechwiedza” czy „doskonałe dobro”, wtedy gdy są one stosowane do Boga ( $\mathbf{R}$ - rzeczywistości). Te próby wydają się obiecujące, choć, rzecz jasna, rodzą pewne trudności ${ }^{31}$.

Reasumując, powiedzieć można, że język, jakim mówimy o R - rzeczywistości, winien to być język J*, który byłby w stosunku do języka J wzbogacony o pewną (niezbyt dużą) liczbę terminów użytych w swoiście analogiczny sposób. To wzbogacenie winno być ilościowo niewielkie oraz rzeczowo uzasadnione.

Drugim zadaniem filozofii religii byłoby poddanie analizie rozmaitych dowodów na istnienie Boga, względnie przedstawienie nowych propozycji $w$ tym zakresie. Te tzw. dowody to dosyć zróżnicowany zbiór racjonalnych (odwołujących się do rozumu) argumentów, mających dostarczyć racji na rzecz tezy o istnieniu Boga. Należy zauważyć, że problematyka ta nie jest całkowicie niezależna od zagadnień przed chwilą rozważanych, to jest od problemów języka religii. Łatwo zauważyć, że pewne stanowiska dotyczące języka religii i jego znaczenia mają istotny wpływ na kwestię tego, jak widzi się możliwość argumentacji na rzecz istnienia Boga. W prypadku stanowiska typu neopozytywistycznego, jak choćby tego reprezentowanego przez A. Ayera, traktowanie $\mathbf{R}$ - wypowiedzi jako pozbawionych znaczenia oznacza, że nie ma możliwości przedkładania argumentów, posiadających jakieś walory poznawcze. Z kolei podej-

${ }^{29}$ Por. R. S w i n b u r n e, Spójność..., s. 94 i nast.

30 Tamże, s. 114.

31 Tamże, s. 145-311, passim. Por. także T. S z u b k a, Analityczna filozofia religii Richarda Swinburnéa, [w:] R. S w i n b u r n e, Spójność..., s. 15-24. 
ście L. Wittgensteina i jego koncepcja języka religijnego czyni niemożliwe i skądinąd niepotrzebne dążenie do jakiegoś argumentowania (uzasadniania) poglądu teistycznego.

Istniejące na gruncie metafizyki zachodniej rodzaje argumentów są zróżnicowane. Immanuel Kant, jak wiadomo, wyróżniał argumenty ontologiczne, kosmologiczne i teleologiczne ${ }^{32}$. Faktyczna analiza rozmaitych rodzajów argumentów, historycznie i współcześnie stosowanych, pozwala jednak na wskazanie takich, które nie mieszczą się w kantowskim katalogu. Mówi się bowiem o argumentach: moralnych, pragmatycznych, z doświadczenia religijnego i wielu innych. Naszym celem nie jest aspirujący do szczegółowości krytyczny przegląd wykorzystywanych argumentów. Chciałbym jedynie zastanowić się nad tym, co one wnoszą do dyskusji i które z nich współcześnie zdają się mieć kluczowe znaczenie. Istniejące argumenty podzielimy na dwie kategorie: a) argumenty aprioryczne; b) argumenty aposterioryczne ${ }^{33}$. Tak te dwa rodzaje charakteryzuje John Hick: „Pośród tradycyjnych argumentów teistycznych powszechnie rozróżnia się argumenty mające charakter a priori lub a posteriori. Argument a posteriori oparty jest na przesłance wywiedzionej z doświadczenia (a zatem po nim lub później od niego). Dlatego też aposterioryczne argumenty za istnieniem Boga wywodzą naturę bóstwa z danych naszego ludzkiego doświadczenia. Natomiast dowód a priori ma podstawę logicznie wcześniejszą, niezależną od doświadczenia. Opiera się on na czysto logicznych rozważaniach i, jeśli jest prawomocny, osiąga ten rodzaj pewności, jaki cechuje prawdy matematyczne"34.

Argument zwany ontologicznym, czy raczej rodzina argumentów tego rodzaju, został zapoczątkowany przez św. Anzelma w jego Proslogionie $e^{35}$. Spotykamy go później u Kartezjusza, Gottfrieda Leibniza, a współcześnie w dyskusjach, które nasiliły się od drugiej połowy XX wieku. W przypadku św. Anzelma, będącego twórcą tego argumentu, Bóg jest to dla niego

32 Por. I. Ka n t, Krytyka czystego rozumu, przeł. R. Ingarden, t. 2, Warszawa 1957, S. 332-333.

33 Tak widzą ten podział niektórzy autorzy. Por. J. H i c k, Argumenty za istnieniem Boga, przeł. M. Kuniński, Kraków 1994, s. 35-41; I. Z i e m i ń s k i, Argumenty za istnieniem Boga, [w:] S. T. K o ł o d z i e j c z y k, Przewodnik po metafizyce, Kraków 2011, s. 550-552.

34 Por. J. H i c k, Argumenty..., s. 35.

35 Ten typ argumentu określany bywa następująco: „The term »ontological argument « was Kant's name for one number of a family of arguments that began with Anselm of Canterbury. These arguments all try to prove God's existence a priori, via reasoning about the entailments of a particular description of God. The description almost always inuolves God's greatness or perfection". Por. B. Le f t o w, The Ontological Argument, [w:] The Orford Handbook of Philosophy of Religion, ed. W. J. Wainwright, Orford 2005, s. 80. 
„coś, ponad co nic większego nie może być pomyślane ${ }^{36}$. To zaś, ponad co nie może być pomyślane nic większego, nie może istnieć tylko $w$ intelekcie. Gdyby tak bowiem było, to owo coś nie spełniałoby tego wymagania, czyli nie byłoby czymś, ponad co nic większego nie może być pomyślane. O ile zaś takie coś (taki byt), ponad które nic większego nie może być pomyślane, istniałoby tylko $w$ umyśle, to byłoby czymś sprzecznym. A jeśli tak, to istnieje ono niewątpliwie tak $w$ intelekcie, jak i $w$ rzeczywistości. Ten argument, krytykowany przez tajemniczego Gaunilona, był dyskutowany $w$ średniowieczu i przez jednych przyjmowany (Bonawentura), przez innych zaś odrzucany (Tomasz z Akwinu) ${ }^{37}$. W czasach nowożytnych głosił go Kartezjusz, sam ten argument bywał zresztą określany mianem kartezjańskiego. Dla Kartezjusza Bóg jest bytem najdoskonalszym z możliwych i nie można pomyśleć Boga jako nieistniejącego, tak samo jak nie można pomyśleć góry bez doliny. Tak jak góra i dolina są nierozdzielne, tak samo istnienie jest nierozdzielne od Boga, co prowadzi do uznania, że Bóg istniej $^{38}$. Argumentacja tego rodzaju żywotna $w$ nowożytności została poddana zasadniczej krytyce przez I. Kanta ${ }^{39}$. Wskazywał on, że konieczność przypisywana sądom nie jest absolutną koniecznością rzeczy. Stąd też jeśli rozpatrujemy sąd „Bóg jest konieczny”, to mamy sąd konieczny. Ale jeśli stwierdzamy, że Bóg nie istnieje, to usuwamy tak sam podmiot, jak i jakąkolwiek jego cechę. Usunięcie orzeczenia danego sądu wraz z podmiotem nie rodzi sprzeczności wewnętrznej ${ }^{40}$. I. Kant podniósł, że słowo „istnienie” to nie jest realne orzeczenie, lecz uznanie $w$ istnieniu pewnej rzeczy ${ }^{41}$. Gdy mamy więc pojęcie Boga („najwyższej realności”), to zawsze jeszcze pozostaje kwestia, czy On istnieje. W efekcie trud budowania dowodu ontologicznego (kartezjańskiego) I. Kant uznaje za daremny.

36 Por. Anzelm z Ca nterbury, Proslogion, [w:] te nże, Monologion. Proslogion, przeł. T. Włodarczyk, Warszawa 1992, s. 145-147. Dowód Anzelma z rozdziału 2 Proslogionu (s. 145-146) różni się nieco od dowodu z rozdziału 3 (s. 146-147).

37 Por. Ś w. To m a s z, Summa..., s. 37-39; także L. E I d e r s, Filozofia Boga. Filozoficzna teologia Św. Tomasza z Akwinu, Warszawa 1992, s. 71-73.

38 Por. R. D e s c a r t e s, Medytacje o pierwszej filozofii, przeł. M. i K. Ajdukiewiczowie, t. 1, Warszawa 1958, s. 87-89.

39 Por. I. Ka n t, Krytyka..., s. 333-344.

40 Tamże, s. 336.

41 Stąd też I. Kant stwierdza: „Jeżeli biorę podmiot (Boga) wraz ze wszystkimi jego orzeczeniami (Praedikate) (do których należy i wszechmoc) i powiadam »Bóg istnieje» (Gott ist) lub też »istnieje jakiś Bóg« (es ist ein Gott), to nie dodaję żadnego nowego orzeczenia do pojęcia Boga, lecz tylko uznaję $w$ istnieniu podmiot sam $w$ sobie ze wszystkimi jego orzeczeniami, a mianowicie przedmiot $w$ jego stosunku do mego pojęcia". Por. tamże, s. 340 . 
W dobie pokantowskiej sam ten dowód bywał zwykle traktowany jako mający walory historyczne, co nie przeszkadza wybitnym uczonym, na przykład Fregemu, zajmować się nim. Zmiana zaszła $w$ drugiej połowie XX wieku, kiedy to rozwój nowych narzędzi logicznych (logiki modalne) spowodował odrodzenie merytorycznego zainteresowania dowodem ontologicznym. Budzi on zainteresowanie znaczących filozofów, jak: Norman Malcolm, Charles Hartshorne, Nicholas Rescher czy Alvin Plantinga ${ }^{42}$. Wykorzystując nowe narzędzia logiczne, często sięgają oni do samej argumentacji anzelmiańskiej ${ }^{43}$. W tym miejscu zatrzymajmy się krótko nad analizami Aluina C. Plantingi ${ }^{44}$. Filozof ten traktuje kantowską krytykę argumentu ontologicznego jako chybioną ${ }^{45}$. Własny argument A. Plantingi ma charakter modalny. Wychodzi on od pojęć maksymalnej doskonałości i maksymalnej wielkości. Maksymalna doskonałość oznacza wszechmoc, wszechwiedzę i moralną doskonałość. Maksymalna wielkość przysługuje bytom maksymalnie doskonałym $w$ każdym możliwym świecie. Maksymalna wielkość to pojęcie możliwe, a więc zrealizowane w jakimś możliwym świecie. Jeśli zaś coś (pewien byt) jest maksymalnie wielkie $w$ jakimś możliwym świecie, to jest maksymalnie wielkie $w$ każdym możliwym świecie. A jeżeli tak, to także $w$ świecie rzeczywistym. To zaś oznacza, że taki byt maksymalnie doskonały istnieje. Warto przy tym pamiętać, że A. Plantinga nie traktuje tego argumentu jako potwierdzenia prawdziwości teizmu, lecz jedynie jako potwierdzenie uznania teizmu jako stanowiska racjonalnego.

Dowody zwane aposteriorycznymi odwołują się do rozmaitych faktów występujących w świecie. Znajdujemy je w tradycji filozoficznej, od Platona poczynając ${ }^{46}$. W myśli zachodniej klasycznym ich wyrazem jest pięć dróg św. Tomasza. Te argumenty mają bogatą literaturę, wywołując zainteresowanie wielkich filozofów przeszłości i współczesności. Charakterystyczne

${ }^{42}$ Interesowano się tym dowodem także $w$ środowisku logicznym, czego najlepszym przykładem jest K. Gödel.

43 Należy zauważyć, że różnią się oni co do tego, która z wersji argumentu ontologicznego $w$ Proslogionie jest najważniejsza: czy ta z rozdziału drugiego (tak chce B. Leftow), czy też ta z trzeciego (tak sądzi N. Malcolm).

44 Por. A. P l a n t i n g a, Bóg, wolność i zło, przeł. K. Gurba, Kraków 1995, s. 134-141; t e n ż e, God and Other Minds, Ithaca-New York 1967, s. 29-38.

45 Anzelm bowiem, zdaniem A. Plantingi, nie dodawał istnienia do pojęcia, w stosunku do którego miałoby ono zastosowania. I. Kant ponadto, ani nikt inny, nie wykazał, że istnienie nie jest predykatem.

46 Por. R. Pr u s s, R. M. G a l e, Cosmological and Design Arguments, [w:] The Orford Handbook..., s. 116-137; W. L. Row e, Cosmological Arguments, [w:] A Companion..., s. 331-337; J. H i c k, Argumenty..., s. 90-109; I. Z i e m i ń s k i, Argumenty..., s. 570-59o. 
jest, że dowody te posiadają podobną strukturę ${ }^{47}$. Wychodzi się od tego, co ma charakter zmysłowy, zaś dochodzi do Boga. Mamy w nich do czynienia z wykorzystywaniem zasady racji dostatecznej. Trzy pierwsze z dróg (er motu, z przyczynowości sprawczej i z przygodności) zakładają, że czymś, co jest wykluczone, byłoby istnienie nieskończonego szeregu. Zakłada się także tezę co do natury bytu boskiego jako jedynego bytu samoistnego. Drogi św. Tomasza można umieścić $w$ ramach schematu modus ponens. I tak przyjmuje się, że jeśli istnieje byt przygodny, to istnieje byt konieczny i istnieje byt przygodny, a więc istnieje też byt konieczny. Choć argumenty te podlegały rozmaitej krytyce, to zarówno w średniowieczu, jak i w nowożytności spotykamy podobne, by wymienić tylko Dunsa Szkota, G. Leibniza, S. Clarke’a i Kartezjusza. Argumentacja aposterioryczna, konkretyzująca się $w$ wielu swoistych argumentach, pojawia się $w$ arsenale filozoficznym myślicieli współczesnych. W tym miejscu zatrzymajmy się tylko nad rozważaniami prowadzonymi przez R. Swinburne’a, przekonanego o walorze argumentacji typu aposteriorycznego. Wskazuje on, że teizm jest stanowiskiem, które wyjaśnia świat mający być skutkiem działań bytu osobowego. Bóg to osoba posiadająca intencje, przeświadczenia i moc sprawczą. Tak rozumiany Bóg jest wszechmocny, wszechwiedzący i całkowicie wolny ${ }^{48}$. Filozof brytyjski stara się wykazać zgodność tych cech i spójność pojęcia bytu boskiego, co czyni w drugim tomie swej trylogii ${ }^{49}$. Bóg jest źródłem wszystkiego i odróżnia się od reszty świata. Hipoteza teizmu jest maksymalnie prosta, redukująca wyjaśnianie do wyjaśniania osobowego. Dzieje się to $w$ ten sposób, że funkcjonowanie i przyczynowo skuteczne działanie czynników danych w wyjaśnianiu naukowym musi być każdorazowo wytłumaczone przez odwołanie się do działania osoby. Stąd wedle R. Swinburne'a teizm to proste przedstawienie poglądu na świat. Pytaniem dla teisty jest to, czy hipoteza teizmu ma prawdopodobieństwo wyjściowe i odpowiednią moc eksplanacyjną ${ }^{50}$. Prawdziwość teizmu oznacza obecność kompletnego wyjaśnienia wszystkiego i to wyjaśnienia, które zamyka się, wskazując na Boga. I właśnie prostota teizmu ma być głównym czynnikiem jego wewnętrznego prawdopodobieństwa, wyższego niż w przypadku konkurencyjnych hipotez. Tak więc dla R. Swinburne'a ten argument mający aposterioryczny charakter nie prowadzi do pewności, lecz dostarcza satysfakcjonującego prawdopodobieństwa. Podobnie jak argument ontologiczny u A. Plantingi, prowadzi on do uznania tezy o istnieniu Boga za racjonalnie akceptowalną.

47 Co do analizy tych dowodów por. L. E I d e r s, Filozofia ..., s. 90-146.

48 Por. R. S w i n b u r n e, The Eristence of God, Orford 1979, chapt. 5.

49 Por. t e n ż e, Spójność..., s. 145-392.

50 Por. t e $\mathrm{n} \dot{z} \mathrm{e}$, The Existence... 
Powyższa krótka refleksja nad argumentem ontologicznym i aposteriorycznym pozwala na sformułowanie pewnych ogólnych uwag $w$ tym zakresie:

1) Współcześnie mamy $w$ filozofii do czynienia tak $z$ argumentacją typu a priori, jak i a posteriori. Przy czym odnowienie zainteresowań rzeczowych argumentem ontologicznym nastąpiło $w$ drugiej połowie $\mathrm{XX}$ wieku.

2) Przyczyny ponownego zainteresowania argumentem ontologicznym są złożone. Stosownych narzędzi dostarczył rozwój logiki. Z pewnością stało się tak także dlatego, że argument ten dotyka kilku ważnych, jakoś z nim związanych kwestii filozoficznych. Chodzi o to, czy istnienie jest własnością czy też nie. Nadto wiąże się z nim pytanie dotyczące tego, czy zdania egzystencjalne mogą być koniecznie prawdziwe. Wielu autorów zajmujących się problemem dowodu ontologicznego wskazuje też, że argument ten, choć intuicyjnie trudny do przyjęcia, cechuje się tym, że trudno wskazać jego bezdyskusyjne usterki.

3) Argument aprioryczny, choć budzi zainteresowanie i niekiedy fascynację filozofów, to pozostaje zwykle poza obszarem zainteresowań zwykłych (niebędących filozofami) wyznawców religii.

4) Argumenty aposterioryczne, w rozmaitych wersjach, których wyżej nie omawialiśmy, są także przedmiotem zainteresowania współczesnych filozofów. Zarazem jednak argumenty tego typu, w przeciwieństwie do argumentu ontologicznego, budzą często zainteresowanie zwykłych ludzi religijnych.

5) Argumenty aposterioryczne wydają się posiadać współcześnie szczególne walory, także z uwagi na to, że wymagają niekiedy sięgania do nauk szczegółowych. Mogą być więc atrakcyjne dla osób o mentalności naukowej i obytych z metodami badań tychże nauk.

6) Filozofowie analizujący te dwa typy argumentów dochodzą do rozmaitych wniosków co do ich wartości argumentacyjnej. Jednak na ogół także ci, którzy widzą ich walory mające przemawiać na rzecz teizmu, nie traktują ich zwykle jako konkluzywnej argumentacji, która zamyka dyskusję, lecz raczej jako argumenty, które przemawiają za racjonalnością stanowiska teistycznego ${ }^{51}$.

51 Spotyka się jednak daleko idące nadzieje związane z argumentacją na rzecz teizmu. I tak wedle M. Dummetta: „[...] czy filozofia może rozstrzygnąć to, co jest bez wątpienia najważniejszym ze wszystkich pytań, mianowicie czy istnieją racjonalne podstawy wiary $w$ istnienie Boga? Wydaje mi się, że istnieją wszelkie powody, aby sądzić, że filozofia jest do tego zdolna i może się to stać już za życia naszych prawnuków". Por. te n ż e, Natura i..., s. 179 . 
Prezentowane powyżej uwagi dotyczyły obydwu ważnych sfer, wtedy gdy analizujemy $\mathbf{R}$ - rzeczywistość, to jest języka religii i argumentacji na rzecz istnienia Boga. To, co $w$ tym zakresie może osiągnąć filozofia, starałem się pokazać. Sądzę, że udało się, w jakimś stopniu, uwydatnić jej swoistość. Filozof różni się bowiem od psychologa religii, który skupia się na komponencie psychicznym religii, od historyka badającego jej przeszłość czy od fenomenologa religii, dla którego istotne jest badanie rozmaitych form przejawiania się religii $w$ aspekcie synchronicznym. Różni się także, co oczywiste, od teologa, który podchodzi do religii niejako od wewnątrz niej samej. Filozofia zaś jest dziedziną autonomiczną. Tak więc filozof, niezależnie od swych przekonań religijnych czy ich braku, winien traktować przedmiot swych badań („warstwę intelektualną religii") w sposób bezstronny. Cóż jednak owa bezstronność miałaby tutaj znaczyć? Pewną uwagę w tym zakresie znajdujemy u Michaela Dummetta, który kieruje je do filozofa religijnego: „Osoba wierząca, która poświęca się filozofii, nie może czynić tego z zamiarem sformułowania argumentów $w$ obronie głównych zasad jej religii - w przeciwnym razie przestanie postępować jak filozof i upodobni się do adwokata czy apologety. Jako filozof musi on podążać tam, gdzie prowadzi go argumentacja"52.

Rozumieć tę opinię można chyba tak, że filozof nie powinien skupiać się na budowie tylko takich argumentów, które zgodne są z jego prefilozoficznymi nastawieniami, pomijając czy też lekceważąc argumenty z tym niezgodne. Jeśli tak rozumieć to ostrzeżenie $M$. Dummetta, to można odnieść je tak do filozofa teisty, jak i agnostyka czy ateisty. Każdy $z$ nich bowiem jest tutaj $w$ podobnej sytuacji.

Rodzi się na koniec pytanie, co rozważania filozoficzne wnoszą do refleksji nad religią. Mówiąc krótko, rozjaśniają one język, którym mówi się o $\mathbf{R}$ - rzeczywistości i pozwalają nadto oszacować wartość prezentowanych argumentów. Znając jednak sporność tych argumentów czy argumentacji filozoficznej w ogóle, można powątpiewać, czy filozofia dostarczyć może wystarczających racji dla kogoś, kto chce ukształtować w sobie religijną czy areligijną postawę. W tym bowiem zakresie filozofia i jej możliwości wydają się ograniczone. Jeśli nawet posiadałbym argument konkluzywny na rzecz istnienia Boga, to jest to za mało, abym, tylko na tej podstawie, stał się wyznawcą chrześcijaństwa, religijnym Żydem czy też muzułmaninem. Osobną kwestią jest pytanie, czy zwykły wyznawca religii, niebędący filozofem, ma obowiązek poszukiwania filozoficznych uzasadnień dla swych religijnych przekonań. W tej kwestii sądzę,

${ }^{2}$ Por. tamże, s. 55. 
że taki wyznawca winien znać doktrynę swej religii i dysponować jakimiś racjami, w oparciu o które ją wyznaje. Czy jednak powinien $w$ tym celu sięgać do arsenału filozoficznego? Odpowiem na to pytanie, może nieco przewrotnie, w sposób następujący: taki wyznawca jest zobowiązany do sięgania po argumenty filozoficzne $w$ tym samym stopniu, $w$ jakim normalny człowiek, podejmujący decyzję moralną, winien sięgać do narzędzi z zakresu metaetyki, aby uzasadnić swój moralny wybór. 